\title{
Effect of cereal products supplementation with american blueberries, cranberries and cinnamon on the formation of type $A$ and $B$ trichothecenes group
}

\author{
Piotr Pokrzywa ${ }^{1, A-D \oplus}{ }^{\circ}$ Ewa Cieślikk ${ }^{2, A, E-F}{ }^{\oplus}$, Magdalena Surma ${ }^{2, C-D \oplus}$ \\ ${ }^{1}$ Regional Sanitary-Epidemiological Station in Department of Food Hygiene, Nutrition and Teaching Processes, Krakow, \\ Poland \\ ${ }^{2}$ Malopolska Centre of Food Monitoring, Faculty of Food Technology, University of Agriculture, Krakow, Poland \\ A - Research concept and design, B - Collection and/or assembly of data, C - Data analysis and interpretation, \\ $D$ - Writing the article, E-Critical revision of the article, F - Final approval of article
}

Pokrzywa P, Cieślik E, Surma M. Effect of cereal products supplementation with american blueberries, cranberries and cinnamon on the formation of type A and B trichothecenes group. Ann Agric Environ Med. 2021; 28(1): 72-80. doi: 10.26444/aaem/116903

\begin{abstract}
Introduction. Mycotoxins - secondary mould metabolites with undesirable effects for humans - are common in the environment. These toxins are mainly produced by fungi of the genera Penicilium, Aspergillus and Fusarium.

Objective. The aim of this study was to evaluate the applicability of various sources of antioxidants (blueberries lyophilisate, cranberries lyophilisate and cinnamon powder), at 5 different concentrations (3\%,5\%, 10\%, 20\%, 30\%), to inhibit the formation of mycotoxins during the storage of cereal products. Analysed cereal samples included selected cereal grains, bran and cereal products intended for consumption by children.

Results. The results showed that supplementation of oat brans with the highest concentrations of blueberry lyophilisate resulted in a significant decrease in the mycotoxins levels; specifically: $20 \%$ concentration reduced the level of HT- 2 toxin by $10.7 \%$ in one sample, while $30 \%$ concentration reduced it by $9.4 \%$ and $17.4 \%$ in 2 other samples. A similar result was measured for oat bran samples supplemented with the cranberry lyophilisate: specifically, $20 \%$ concentration significantly reduced the level of HT- 2 toxin by $10.6 \%$ in one sample, while $30 \%$ concentration reduced it by an average of $18.0 \% \pm 6,0 \%$ in 5 other samples. Finally, cinnamon powder supplementation caused a significant reduction in HT- 2 levels in all stored samples, even at its lowest concentration. $30 \%$ supplementation resulted in HT-2 reduction in cereal samples by $67.1 \%-$ $76.1 \%$, in wheat bran samples by $57.5 \%-69.2 \%$, in oat bran samples by $83.4 \%-87.0 \%$ and by $55.0 \%-100 \%$ in samples of cereal products intended for consumption by children.
\end{abstract}

Conclusions. Natural products used in the experiment (blueberry, cranberry, cinnamon) inhibited the formation of mycotoxins from the group of trichothecenes.

\section{Key words}

trichothecenes, cereals, antioxidant potential, cereals products, mycotoxin reduction, natural phenolic compounds

\section{INTRODUCTION}

Mycotoxins - secondary mould metabolites with undesirable effects for humans - are common in the environment. Their presence is not related to the development of industry or transport. which in the common understanding are considered to be the main factors responsible for the occurrence of food contamination. These toxins are mainly produced by fungi of the genera Penicilium, Aspergillus and Fusarium. Their occurrence is associated with the inevitable presence of mould in the environment [1]. Mycotoxins may enter the food chain indirectly and directly: indirectly by consuming the meat or milk of animals fed with the contaminated products, or directly by consuming plant products contaminated in the field or during storage or processing [2]. Vegetable products such as cereals, oilseeds, coffee, fruits, spices and nuts, as well as animal products (milk, meat, offal), are all susceptible to

Address for correspondence: Piotr Pokrzywa, Regional Sanitary-Epidemiological Station in Department of Food Hygiene, Nutrition and Teaching Processes, Krakow, Poland

E-mail: p.pokrzywa@wsse.krakow.pl

Received: 29.09.2019; accepted: 15.01.2020; first published: 05.03.2020 mycotoxin contamination [3]. The most frequently occurring mycotoxins include aflatoxins, ochratoxin $\mathrm{A}$, patulin and a group of toxins produced by certain fungi species of the genus Fusarium (trichothecenes, fumonisins, moniliformin $(\mathrm{MON})$, zearalenone (ZEA) and its derivatives). Four types are distinguished among the trichothecenes: A, B, C and D. Type A trichothecenes, produced by F. sporotrichiodies and F. Poae, include T-2 toxin, HT-2 toxin and diacetoxyscirpenol (DAS). Type B trichothecenes include deoxynivalenol (DON), nivalenol (NIV) and fusarenone-X (FUS). Type A trichothecenes are generally considered more toxic than Type B trichothecenes [4]. The maximum acceptable levels of aflatoxins, ochratoxin A, patulin, deoxynivalenol and zearalenone, fumonisins ( $\operatorname{sum} \mathrm{B}_{1}$ and $\mathrm{B}_{2}$ ), citrin and ergot alkaloids are established by the European Commission Regulation (EC) No. 1881/2006 from 19 December 2006 [5]. In 2013, the European Commission issued recommendations on the presence of T-2 and HT-2 toxin in cereals and cereal products [6].

The growth of Fusarium and the production of mycotoxins depend on multiple environmental factors, which include substrate composition, its consistency, presence of 
micronutrients, presence of accompanying microflora, and above all, humidity and temperature.

Numerous studies are available on the effect of temperature on the growth of selected Fusarium species and the production of T-2 and HT-2 toxins. Mylona and Magan [7] reported $25^{\circ} \mathrm{C}$ as optimal for Fusarium to produce the T-2 and HT-2 toxin in oats. Similarly, a range between $20-30^{\circ} \mathrm{C}$ was reported by Medina and Magan [8].

Several detoxification methods are known to prevent the mycotoxin contamination of food products; however, most of them are not being commonly applied due to their high costs or impracticality [9]. In order to limit losses during post-harvest storage of food products, synthetic organic compounds are currently applied. Unfortunately, many of those compounds have the potential for adverse impact on the environment, consumers safety and development of resistance in pest species. As a result, there is an increasing need for safer, ecological and biodegradable alternatives [10]. There are several compounds of natural and synthetic origin that have antioxidant properties and could be implemented to counteract the formation of mycotoxins.

Highbush blueberry and cranberry are a rich source of bioactive compounds with high antioxidant potential. Blueberries are characterized by a high content of polyphenolic compounds, anthocyanins. Levels of anthocyanins vary, ranging $25-495 \mathrm{mg} / 100 \mathrm{~g}$, depending on variety, fruit maturity and size, climate and growing conditions, as well as handling post-harvest storage time and conditions [11]. Cranberries are an exceptionally rich source of phenolic compounds. Their high antioxidant activity is due to the presence of 3 main classes of flavonoids: anthocyanins, flavonols and flavan3-ols [12]. Spices are a separate group with natural high antioxidant potential, containing essential oils, glycosides, alkaloids, bitterness, mucus and tannins. Cinnamon spice is obtained from the tree bark of cinnamomum genus and is particularly rich in antioxidants [13].

Numerous studies have shown that essential oils, obtained from raw plant material, demonstrate a wide range of biological and pharmacological activities. The bioactive constituents of cinnamon are cinnamaldehyde, eugenol, linalool and 1,8-cneolol. Cinnamon oil is recommended for indigestion, severe cramps or bloating, due to its ability to suppress gastrointestinal motility [14]. In addition, essential oils are currently extensively studied due to their antimicrobial and antioxidant properties $[15,16]$. Studying the preventive effect of essential oils against mildew showed that Ocimum basilicum oil at a concentration of $4.8 \mu \mathrm{L} / \mathrm{g}$ significantly reduces the growth of Fusarium verticillioides and the formation of fumonisin in artificially infected corn grain [17].

Chemical preservatives are currently used to protect the food commodities against toxic fungal spoilage. Available data suggest that some known natural compounds can become successful alternatives. In addition, increasing awareness among consumers put pressure on the food industry and food scientists to improve food quality and safety. For those reasons, essential oils, oleoresins and their components extracted from aromatic plants, natural plant extracts and spices attracted increased attention [2, 17].

Numerous studies are available regarding cereals and methods applied to inhibit the fungal growth and mycotoxin production, providing information on species, tested cereals and general growth conditions. Unfortunately, the literature is limited regarding processed foods, including cereal products intended for infants and young children

\section{OBJECTIVE}

The aim of this study was to evaluate the effect of blueberries lyophilizate, cranberries lyophilizate and cinnamon powder as natural sources of bioactive substances, including antioxidants, on the formation of mycotoxins. The results of the above tests may have practical application in the food industry to ensure the health safety of products exposed to mycotoxin contamination.

\section{MATERIALS AND METHOD}

Samples consisted of cereals (wheat, oats), brans (wheat, oats) and cereal products intended for consumption by infants and young children. Wheat and oat grains were obtained directly from the producers (south-eastern Poland). Wheat and oat bran, as well as cereal products intended for consumption by children, were purchased in retail (Krakow). The wheat bran and oat bran did not contain any artificial flavours or additives, and consisted of $100 \%$ of the respective type of grain. Cereal products for infants and children included instant porridge products intended for infants aged from 4 months and for small children, containing a mixture of various cereals (wheat, oats, rye, barley and millet). Highbush (American) blueberry lyophilizate (Vaccinium corymbosum L), cranberries lyophilizate (Vaccinium macrocarpon) and Ceylon cinnamon powder (Cinnamomum verum) were purchased in a health food store. Freeze-dried blueberry and cranberry have a relatively high antioxidant capacity, are widely popular among consumers, and combine well with cereal products. Cinnamon has a significant antioxidant potential as well as an accepted taste and aroma.

Chemicals. Trifluoroacetic acid anhydride (TFAA) and 15-Acetoxyscirpenol (15-MAS) metanol, aceton, Trolox, dipotassium peroxodisulfate were purchased from Sigma, Krakow, Poland. N-(trimethylsilyl)-imidazol (TMSI) and trimethylchlorosilane (TMCS) were obtained from Fluka, Krakow, Poland. T2-Toxin (T-2), HT2-Toxin (HT-2), scirpenol (SCI), 15-monoacetoxyscirpenol(15-MAS), diacetoxyscirpenol (DAS), triacetoxyscirpenol (TAS), fusarenon X (FUS-X), B-trichothecene-mixture solution: nivalenol (NIV), deoxynivalenol (DON), 3-acetyldeoxynivalenol (3-AcDON), 15 -acetyldeoxynivalenol (15-AcDON), were purchased from Riedel-de-Haen, Germany.

Sample preparation. The experiment was carried out in 2 stages. The first stage included the baseline assessment of the antioxidant potential, the degree of Type A and B trichothecenes contamination, and the level of microbiological purity (total number of moulds) in all raw materials: cereal and bran samples, cereal products for children, blueberry and cranberry lyophilizate and cinnamon powder. The moisture content of each individual sample was determined according to the method described in ISO 712:2009 report [18]. Samples were analyzed for total number of colonies according to the method described in the standard $[19,20]$. The second stage involved only samples deemed contaminated. 
Each cereal sample was milled and supplemented with blueberry lyophilizate, cranberry lyophilizate and cinnamon powder at 5 different concentrations (3\%, 5\%, 10\%, 20\%, 30\%). In order to provide favourable conditions for fungal growth, humidity was set at $19 \%$ by adding an appropriate amount of distilled water. Samples were then stored at $28^{\circ} \mathrm{C}$ for 14 days. After this storage period, the antioxidant potential and the levels of Type A and B trichotheses were determined. A total of 189 samples were tested and a total of 2,272 analyses made (Fig. 1).
Determination of the antioxidant potential. The antioxidative potential of the tested samples was determined by measuring their quenching capacity of ABTS + + free radical and expressed in micromoles of trolocyte equivalents (TEAC - Trolox Equivalent Antioxidant Capacity) per $1 \mathrm{~g}$ sample $(\mu \mathrm{mol} \mathrm{TE} / \mathrm{g})$ [21]. $3 \mathrm{~g}$ of each tested sample was extracted with $40 \mathrm{ml}$ of $0.08 \mathrm{M} \mathrm{HCl}$ in $80 \%$ methanol at $18-22^{\circ} \mathrm{C}$ for $2 \mathrm{~h}$. The extract was then centrifuged at $1,500 \times \mathrm{g}$ for $15 \mathrm{~min}$. The supernatant was preserved, and the sample re-extracted with $40 \mathrm{ml}$ of $70 \%$ acetone for a further $2 \mathrm{~h}$. After centrifugation $(1,500 \times \mathrm{g}, 15 \mathrm{~min})$ the supernatant was combined with the
Grain, bran, cereal products for children, blueberry and cranberry lyophilizate, Ceylon cinnamon powder

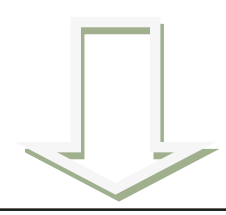

Samples of grains, brans and cereal products for children, milled and supplemented with blueberry lyophilizate, cranberry lyophilizate and cinnamon at 5 different concentrations $(3 \%, 5 \%, 10 \%, 20 \%, 30 \%)$ plus controls PREPARED FOR STORAGE.

Storage at $28^{\circ} \mathrm{C}$ for 14 days

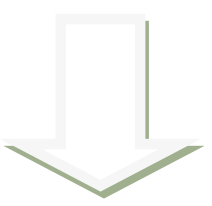

Samples of grains, brans and cereal products for children milled and supplemented with blueberry lyophilizate, cranberry lyophilizate and cinnamon at 5 different concentrations $(3 \%, 5 \%, 10 \%, 20 \%, 30 \%)$ plus controls AFTER STORAGE.
Antioxidant potential, mycotoxin contamination, total number of molds,

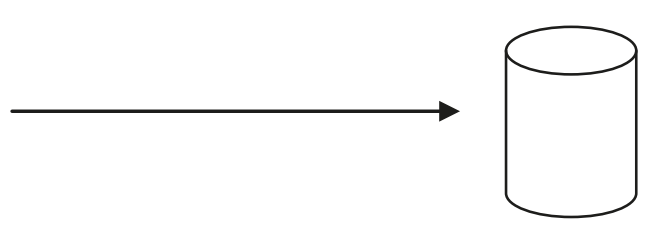

Antioxidant potential, mycotoxin contamination

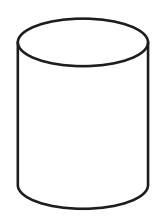

Antioxidant potential, mycotoxin contamination 
previous one. Extract was then stored at $-20^{\circ} \mathrm{C}$. ABTS + was dissolved in a solution of dipotassium peroxysulfate and then diluted until its absorbance at $734 \mathrm{~nm}$ was $0.740-0.750$. Samples containing $0.35 \mathrm{ml}$ of methanol-acetone extracts were made up to $1 \mathrm{ml}$ with acetone-methanol solution (1:1), mixed with $2 \mathrm{ml}$ of ABTS solution and incubated at $30^{\circ} \mathrm{C}$ for $6 \mathrm{~min}$. The absorbance was then measured at $734 \mathrm{~nm}$ relative to the methanol-acetone (1:1) solution. Standard 1 M Trolox solution was prepared to create a methanol-diluted standard curve. Each sample was prepared in triplicate.

Mycotoxins analysis. Samples were analyzed for the presence of trichothecenes according to Jeleń and Wąsowicz [22]. $25 \mathrm{~g}$ of each sample was extracted in $100 \mathrm{ml}$ acetonitrile for $2 \mathrm{hrs}$, and then filtered through a paper filter.

To analyse the type A trichothecenes (T-2, HT-2, DAS, SCI, $15 \mathrm{MAS}, \mathrm{TAS}), 1 \mathrm{ml}$ of the filtrate was evaporated to dryness and then re-disolved in $200 \mathrm{ml}$ of trifluoroacetic acid (TFA). Obtained solution was then heated at $60^{\circ} \mathrm{C}$ for 20 minutes. After cooling, the solution was again evaporated to dryness and finally redissolved in $1 \mathrm{ml}$ of isooctane.

To analyse the type B trichothecenes (DON, 3-Ac-DON, FUS-x, NIV, 15-Ac-DON), $100 \mu \mathrm{l}$ of trimethylchlorosilane (TMCS) was added to $1 \mathrm{ml}$ of the filtrate. Obtained solution was incubated for $20 \mathrm{~min}$ at room temperature. $400 \mu \mathrm{l}$ of isooctane and $0.5 \mathrm{ml}$ of water were then added, the sample vortexed and incubated for 10-20 min until phase separation. The isooctane layer was used for the analysis. Isooctane sample extracts were analysed using a 2-dimensional gas chromatograph coupled with a Time-of-Flight Mass Spectrometer (GCxGC-TOFMS) Pegasus 4D (Leco). Each sample was prepared in triplicate.

Enumeration of total moulds by colony count. The fungal colony count was calculated using the plate count method described by the appropriate ISO $[19,20]$. For each sample, a stock sample solution was prepared followed by a series of 10 -fold dilutions. $0.1 \mathrm{~mL}$ of each dilution (including the stock solution) was aseptically innoculated on previously prepared DRBC agar plates or DG18 agar plates. Inculum was then evenly spread until all excess liquid was absorbed. The seeded plates were incubated at $25^{\circ} \mathrm{C} \pm 1^{\circ} \mathrm{C}$ for 5 days, without inverting the plates. Depending on the growth rate, colonies were counted after $2-5$ days of incubation.

Equipment. Quantitative analysis applied 2-dimensional gas chromatography coupled with time-of-flight mass spectrometry $(\mathrm{GC} \times \mathrm{GC}-\mathrm{TOF}-\mathrm{MS}$, Pegasus 4D LECO, St. Joseph, MI, USA). The GC was equipped with a DB- 5 column $(25 \mathrm{~m} \times 0.2 \mathrm{~mm} \times 0.33 \mu \mathrm{m}$, Agilent Technologies, Santa Clara, CA, USA) and $\mathrm{Rxi}^{\oplus}-17(1.2 \mathrm{~m} \times 0.1 \mathrm{~mm} \times 0.1 \mu \mathrm{m}$, Restek Bellefonte, PA, USA) as a second column. For the first 1 minute, the main oven temperature was kept at $80^{\circ} \mathrm{C}$, the oven was then heated at a rate of $20^{\circ} \mathrm{C} / \mathrm{min}-170^{\circ} \mathrm{C}(3 \mathrm{~min})$, from then on at $4^{\circ} \mathrm{C} / \mathrm{min}$ to $240^{\circ} \mathrm{C}(4 \mathrm{~min})$, followed by the rate of $10^{\circ} \mathrm{C} / \mathrm{min}-270^{\circ} \mathrm{C}(5 \mathrm{~min})$. A secondary oven was run at temperatures $10^{\circ} \mathrm{C}$ higher than the main oven. Transfer line was $290^{\circ} \mathrm{C}$. Injection port temperature was $280^{\circ} \mathrm{C}$, splitless mode (60 s), helium flow $0.8 \mathrm{ml} / \mathrm{min}$, ion source temperature $240^{\circ} \mathrm{C}$. Spectra were collected at a rate $50 \mathrm{scans} / \mathrm{s}$ in a range of 100 -700 Da. For 2-dimensional analysis, modulation time was optimized and set at $5 \mathrm{~s}$. Carry $50 \mathrm{UV}$ spectrophotometer (Varian, USA) was used to measure absorbance.
Statistical analysis. Results were analysed using one-way analysis of variance (ANOVA) with a significance level of $\mathrm{p}<0.05$. The correlation as assessed between the antioxidant activity and mycotoxins content.

\section{RESULTS AND DISCUSSION}

The analyzed raw materials demonstrated various antioxidant potential (Tab. 1). The highest antioxidant activity was measured for the cinnamon 1,654.80 $105.21 \mu \mathrm{mol} \mathrm{TE} / \mathrm{g}$. For comparison, the literature reports $1,119.90 \pm 199.2 \mu \mathrm{mol}$ TE/g as the average antioxidant activity for cinnamon [13]. Significantly lower antioxidant activity was measured for the cranberry lyophilizate $18.50 \pm 0.87 \mu \mathrm{mol} \mathrm{TE} / \mathrm{g}$. Those levels are supported by results published for assorted cranberry varieties (ranging from $9.3 \pm 1.2-16.4 \pm 1.2 \mu \mathrm{mol} \mathrm{TE} / \mathrm{g}$ ) by Borowska et al. [23]. Finally, the average antioxidant potential of American blueberry lyophilizate was $19.37 \pm 2.11 \mu \mathrm{mol} \mathrm{TE} / \mathrm{g}$, similar to that measured for the cranberries. Comparable average levels of $18.50 \pm 4.04 \mu \mathrm{mol} \mathrm{TE} / \mathrm{g}$ were demonstrated by Rodrigues et al. [24] for assorted blueberry varieties.

The average antioxidant potential of oat grain was $16.84 \pm 0.53 \mu \mathrm{mol} \mathrm{TE} / \mathrm{g}$ and of wheat grain $12.39 \pm 0.41 \mu \mathrm{mol}$ $\mathrm{TE} / \mathrm{g}$. The average antioxidant activity of wheat bran was $9.84 \pm 0.24 \mu \mathrm{mol} \mathrm{TE} / \mathrm{g}$ and of oat bran was $6.27 \pm 0.23 \mu \mathrm{mol}$ $\mathrm{TE} / \mathrm{g}$, comparable to $9.65 \pm 0.32 \mu \mathrm{mol} \mathrm{TE} / \mathrm{g}$ and $6.45 \pm 0.14 \mu \mathrm{mol}$ $\mathrm{TE} / \mathrm{g}$, determined respectively by Filipiak-Florkiewicz et al. [25]. Lastly, to the best knowledge of the authors of the current study, the data presented is the first to report the average antioxidant potential of cereal products intended for consumption by children. The measured level was $26.78 \pm 1.31 \mu \mathrm{mol} \mathrm{TE} / \mathrm{g}$, higher than that of cereals and bran.

In all cereal and cereal products analyzed samples, detectable amounts of mycotoxins were found for the Type A trichothecenes, namely, HT-2 toxin and diacetoxyscirpenol (DAS). The levels of contamination with HT-2 mycotoxin ranged from 77.93 - $137.18 \mu \mathrm{g} \mathrm{kg}^{-1}$ (Tab. 1). HT-2 toxin was found in the oat grain sample in the amount of $85.3 \mu \mathrm{g} \mathrm{kg}^{-1}$, and in the wheat grain sample at $77.93 \mu \mathrm{g} \mathrm{kg}^{-1}$. In oat bran samples, the presence of this toxin was found at 94.21 and $100.70 \mu \mathrm{g} \mathrm{kg}^{-1}$. In contrast, the content of HT-2 toxin in the wheat bran samples was higher and amounted to $137.18 \mu \mathrm{g} \mathrm{kg}^{-1}$ and $131.67 \mu \mathrm{g} \mathrm{kg}$. DAS toxin was found only in the wheat grain sample at $148.1 \mu \mathrm{g} \mathrm{kg}^{-1}$. No detectable levels of mycotoxins were found in cereal products intended for children.

On 27 March 2013, the European Commission established the indicative values for T-2 and HT-2 toxins [6]. These values for unprocessed cereals are $1,000 \mu \mathrm{g} \mathrm{kg}^{-1}$ for oats and $100 \mu \mathrm{g} \mathrm{kg}^{-1}$ for wheat. For oat bran the value is $200 \mu \mathrm{g} \mathrm{kg}^{-1}$, and for wheat bran $100 \mu \mathrm{g} \mathrm{kg}^{-1}$. The results for the oat grain sample in the current study showed lower than the index value $(8.5 \%$ of the index value) levels of HT-2 toxin, while the content of this toxin in the wheat grain sample was much higher (77.9\% of the index value).

In contrast, the content of HT-2 mycotoxin measured in oat and wheat grains from Croatia [26] were significantly lower, averaging at $7 \mu \mathrm{g} \mathrm{kg}^{-1}$ and $9 \mu \mathrm{g} \mathrm{kg}^{-1}$, respectively. Similarly, lower levels of trichothecenes were found in wheat grain in studies conducted in Poland [27] and Lithuania [28]. The level of HT-2 toxin determined in oat brans was significantly lower than the acceptable values $(47.1 \%$ and $50.4 \%$ of the 
Table 1. Antioxidant potential, mycotoxin conten, and total number of moulds in the research material.

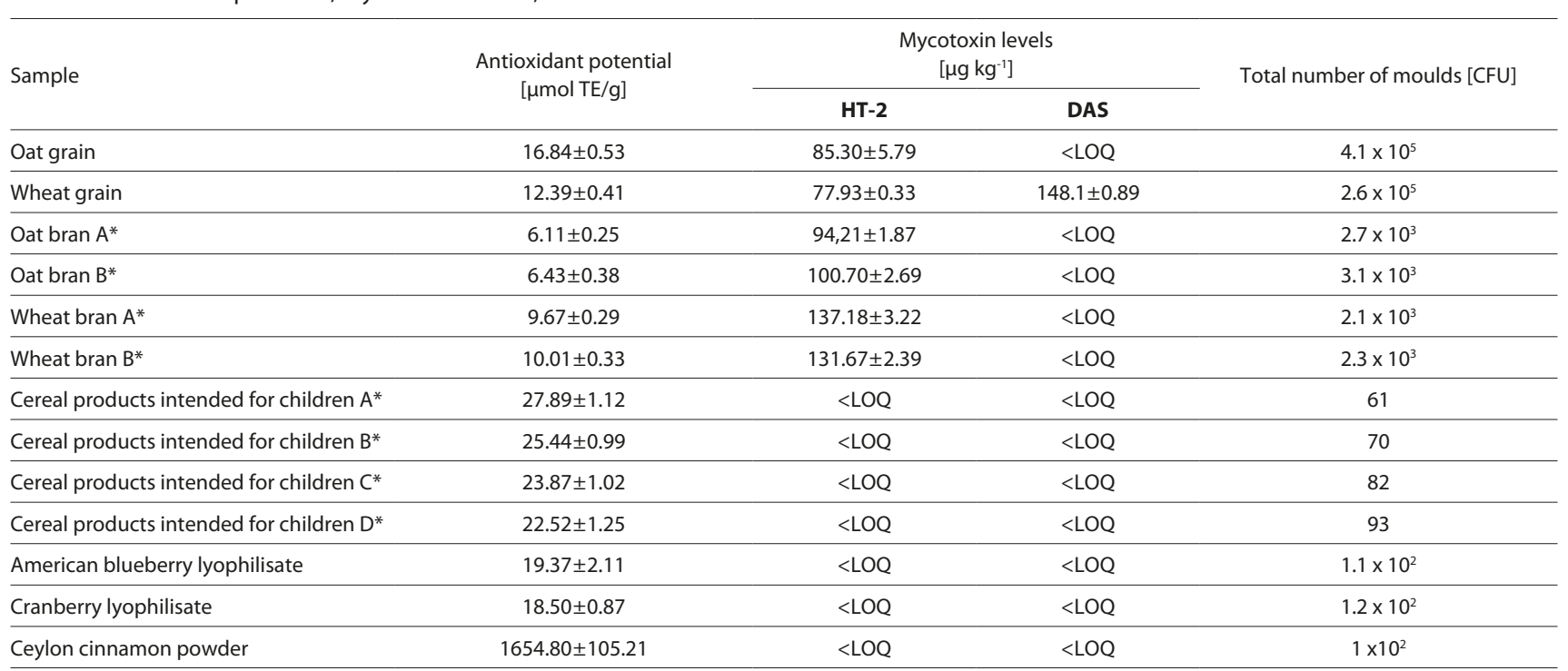

${ }^{*} A, B, C$ and $D$ represent different brands

index value). In contrast, the level of HT-2 toxin in wheat bran exceeded the indicative value $(131 \%$ and $137 \%$ of the index value). Obtained results regarding the content of HT-2 toxin in the wheat and oat bran samples were also higher than those reported by Rodrigeuez-Carrasco et al. [29].

The total number of moulds in all tested products ranged from 61 colonies to $4.1 \times 10^{5}$ [CFU] (Tab. 1), with the highest overall number of moulds found in cereal grain samples. The content of mould in oat grain was $4.1 \times 10^{5}$ [CFU], higher than the value obtained for wheat $\left(2.6 \times 10^{5}\right.$ [CFU]). In the bran group, colonies grew in both oat and wheat bran samples, $3.1 \times 10^{3}$ [CFU] $-2.1 \times 10^{3}$ [CFU]. Higher colonies counts were found for oat bran, an average of $2.9 \times 10^{3}$ [CFU] than wheat, where the average value was $2.2 \times 10^{3}$ [CFU]. Cereal products for children were characterized by much lower counts, between 61 - 93 [CFU]. The grain contamination level was higher than values reported by Stuper-Szablewska \& Perkowski [27] at 1.13 - 2.67 Log CFU per g. Twaróżek et al. [30] also reported a lower average total number of moulds in wheat grain at $1.2 \times 10^{4}$ [CFU]. On the other hand, measured wheat bran mycotoxin contamination was less than the $1.5 \times 10^{4}[\mathrm{CFU}]$ reported by Czerwińska and Kubiak [31] for bran produced from a raw material originating from organic farming. Interestingly, wheat bran obtained from raw material originating from traditional cultivation was characterized by a lower degree of mould contamination than that found in the current study.

The analysis showed a positive correlation between the CFU count in analyzed grain samples and levels of mycotoxin contamination. However, this correlation was either absent for bran samples or inverse.

Supplementation of cereal samples with plant material rich in antioxidants increased the antioxidant potential of oat and wheat both grain and bran, due to the higher antioxidant potential of freeze-dried blueberries and cranberry (Tab. 2). Interestingly, the antioxidant potential of cereal products intended for children decreased when supplemented with those lyophilizates at $20 \%$ and $30 \%$. This was due to the relatively lower antioxidant potential of used supplement compared to the enriched product. Cinnamon significantly increased the antioxidative potential of all samples.

The presented study focused on the applicability of various plant sources of antioxidants (blueberry, cranberry and cinnamon) to inhibit the formation of mycotoxins and showed some inhomogeneous results, depending on the sample as well as the type and amount of supplement added. The $20 \%$ addition of blueberry lyophilizate influenced the level of HT-2 toxin only in one sample of oat bran, inhibiting its formation by $10.7 \%$ in relation to the control (Tab. 3). $30 \%$ concentration of blueberry lyophilizate reduced it by $9.4 \%$ and $17.4 \%$ in both oat bran samples. Interestingly, supplementation of cereal products intended for children with blueberries (at different levels of enrichment) caused an increase in the level of HT-2 toxin in 3 out of 4 samples. It should be noted that the original product had a higher antioxidant potential than the additive, leading to a significant decrease in the antioxidative potential of the supplemented product. No significant changes in the level of mycotoxins were measured for 2 cereal samples (oats, wheat) and 2 samples of wheat bran and one cereal product intended for consumption by children. Correlation analysis showed a strong negative correlation in $90 \%$ of all tested samples. Only one sample of cereal products intended for children showed no linear relationship $(r=0.220)$.

The addition of cranberry lyophilizate had a statistically significant effect on the content of HT-2 toxin in 6 out of 10 samples tested (Tab. 4). A $20 \%$ concentration significantly reduced the level of HT-2 toxin by $10.6 \%$ in one sample, while $30 \%$ concentration reduced it by an average of $18.0 \% \pm 6.0 \%$ in 5 other samples. Cranberry lyophilizate - like the effect of supplementation with blueberry lyophilizate - did not inhibit the formation of mycotoxins in any of the samples of cereal products intended for children. Moreover, in 3 out of 4 samples (30\% supplementation) the level of contamination increased. Correlation analysis showed a very strong negative correlation for $80 \%$ of the tested samples. Two sample of cereal products intended for children showed no linear relationship ( $r=0.263$ and $r=-0.079$ ).

Cinnamon powder supplementation caused a significant dose-dependent reduction in HT-2 levels in all stored samples 
Table 2. Effect of supplementation with antioxidant-rich compounds [ $\mu \mathrm{mol} \mathrm{TE} / \mathrm{g}]$ on antioxidative potential of samples.

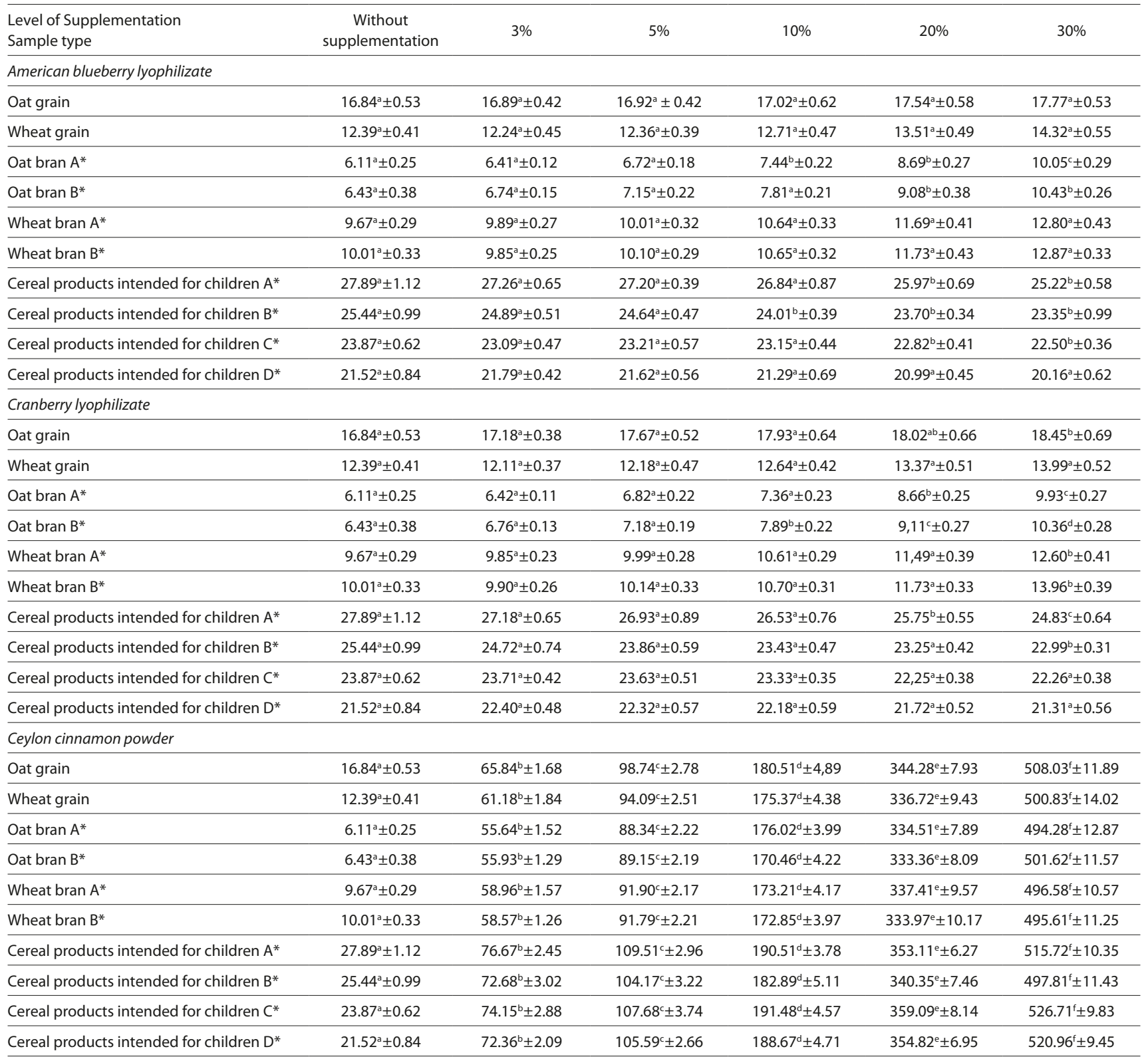

*A, B, C and D represent different brands

$a, b-$ statistically significant difference between mean values designated by the identical letters in rows, $p<0.05$

Table 3. The HT-2 toxin content $\left[\mathrm{\mu g} \mathrm{kg}^{-1}\right]$ in samples supplemented with the blueberry lyophilizate after storage at $28^{\circ} \mathrm{C}$ and $19 \%$ humidity for 14 days

\begin{tabular}{|c|c|c|c|c|c|c|}
\hline $\begin{array}{l}\text { Level of supplementation } \\
\text { Sample type }\end{array}$ & $\begin{array}{c}\text { Without } \\
\text { supplementation }\end{array}$ & $\begin{array}{c}\text { With } 3 \% \text { american } \\
\text { blueberry } \\
\text { lyophilizate }\end{array}$ & $\begin{array}{l}\text { With } 5 \% \text { american } \\
\text { blueberry } \\
\text { lyophilizate }\end{array}$ & $\begin{array}{c}\text { With } 10 \% \text { american } \\
\text { blueberry } \\
\text { lyophilizate }\end{array}$ & $\begin{array}{l}\text { With } 20 \% \text { american } \\
\text { blueberry } \\
\text { lyophilizate }\end{array}$ & $\begin{array}{c}\text { With } 30 \% \text { american } \\
\text { blueberry } \\
\text { lyophilizate }\end{array}$ \\
\hline Oat grain & $90.09^{\mathrm{a}} \pm 3.76$ & $89.60^{\mathrm{a}} \pm 4.01$ & $90.34^{\mathrm{a}} \pm 4.31$ & $90.45^{\mathrm{a}} \pm 3.71$ & $87.17^{\mathrm{a}} \pm 4.13$ & $85.35^{\mathrm{a}} \pm 4.45$ \\
\hline Wheat grain & $88.95^{\mathrm{a}} \pm 3.81$ & $88.94^{\mathrm{a}} \pm 3.94$ & $90.85^{\mathrm{a}} \pm 3.82$ & $91.85^{\mathrm{a}} \pm 3.42$ & $89.43^{\mathrm{a}} \pm 4.10$ & $83.63^{\mathrm{a}} \pm 3.97$ \\
\hline Oat bran $\mathrm{A}^{*}$ & $101.14^{\mathrm{a}} \pm 4.66$ & $105.67^{\mathrm{a}} \pm 5.27$ & $104.48^{\mathrm{a}} \pm 5.09$ & $101.84^{\mathrm{ab}} \pm 5.06$ & $98.81^{\mathrm{ab}} \pm 3.22$ & $91.61^{b} \pm 4.03$ \\
\hline Oat bran B* & $112.27^{\mathrm{a}} \pm 5.26$ & $118.04^{\mathrm{a}} \pm 5.31$ & $115.61^{\mathrm{a}} \pm 5.36$ & $113.33^{\mathrm{a}} \pm 4.53$ & $100.28^{b} \pm 4.14$ & $92.76^{b} \pm 4.21$ \\
\hline Wheat bran $A^{*}$ & $154.41^{\mathrm{a}} \pm 5.76$ & $150.96^{\mathrm{a}} \pm 7.60$ & $156.72^{\mathrm{a}} \pm 8.04$ & $154.07^{\mathrm{a}} \pm 7.37$ & $142.69^{\mathrm{a}} \pm 7.50$ & $141.17^{\mathrm{a}} \pm 6.20$ \\
\hline Wheat bran $B^{*}$ & $152.71^{\mathrm{a}} \pm 6.70$ & $154.53^{\mathrm{a}} \pm 7.60$ & $152.15^{\mathrm{a}} \pm 7.50$ & $153.99^{\mathrm{a}} \pm 8.18$ & $146.88^{\mathrm{a}} \pm 6.96$ & $139.87^{\mathrm{a}} \pm 7.06$ \\
\hline Cereal products intended for children $A^{*}$ & $7.12^{\mathrm{a}} \pm 0.29$ & $6.94^{\mathrm{a}} \pm 0.35$ & $7.22^{\mathrm{a}} \pm 0.33$ & $7.69^{\mathrm{ab}} \pm 0.42$ & $8.54^{b} \pm 0.38$ & $9.86^{\complement} \pm 0.47$ \\
\hline Cereal products intended for children $B^{*}$ & $10.32^{a} \pm 0.61$ & $10.61^{\mathrm{a}} \pm 0.57$ & $9.94^{\mathrm{a}} \pm 0.49$ & $12.74^{b} \pm 0.63$ & $13.54^{\mathrm{bc}} \pm 0.72$ & $14.74^{c} \pm 0.69$ \\
\hline Cereal products intended for children $C^{*}$ & $12.22^{\mathrm{a}} \pm 0.62$ & $12.55^{\mathrm{a}} \pm 0.61$ & $13.14^{\mathrm{ab}} \pm 0.59$ & $12.83^{\mathrm{ab}} \pm 0.68$ & $13.03^{\mathrm{ab}} \pm 0.64$ & $14.34^{b} \pm 0.68$ \\
\hline Cereal products intended for children $D^{*}$ & $22.33^{\mathrm{a}} \pm 0.68$ & $22.79^{\mathrm{a}} \pm 0.74$ & $21.74^{\mathrm{a}} \pm 0.96$ & $22.54^{\mathrm{a}} \pm 0.91$ & $21.73^{\mathrm{a}} \pm 1.02$ & $22.24^{\mathrm{a}} \pm 0.78$ \\
\hline
\end{tabular}

${ }^{*} A, B, C$ and $D$ represent different brands

$a, b-$ statistically significant difference between mean values designated by the identical letters in rows, $p<0.05$ 
Table 4. HT-2 toxin content $\left[\mu \mathrm{g} \mathrm{kg}^{-1}\right]$ in samples supplemented with cranberry lyophilizate,after storage at $28^{\circ} \mathrm{C}$ and $19 \%$ humidity for 14 days.

\begin{tabular}{|c|c|c|c|c|c|c|}
\hline $\begin{array}{l}\text { Level of supplementation } \\
\text { Sample type }\end{array}$ & $\begin{array}{c}\text { Without } \\
\text { supplementation }\end{array}$ & $\begin{array}{l}\text { With } 3 \% \text { cranberry } \\
\text { lyophilizate }\end{array}$ & $\begin{array}{l}\text { With } 5 \% \text { cranberry } \\
\text { lyophilizate }\end{array}$ & $\begin{array}{l}\text { With } 10 \% \text { cranberry } \\
\text { lyophilizate }\end{array}$ & $\begin{array}{l}\text { With } 20 \% \text { cranberry } \\
\text { lyophilizate }\end{array}$ & $\begin{array}{l}\text { With } 30 \% \text { cranberry } \\
\text { lyophilizate }\end{array}$ \\
\hline Oat grain & $89.79^{\mathrm{a}} \pm 3.61$ & $89.65^{\mathrm{a}} \pm 4.35$ & $90.13^{\mathrm{a}} \pm 4.24$ & $90.32^{\mathrm{a}} \pm 3.50$ & $84.87^{\mathrm{ab}} \pm 3.42$ & $76.82^{\mathrm{b}} \pm 3.86$ \\
\hline Oat bran $A^{*}$ & $115.08^{\mathrm{ac}} \pm 5.44$ & $117.74^{\mathrm{ab}} \pm 4.53$ & $114.13^{\mathrm{ac}} \pm 5.39$ & $112.84^{\mathrm{ac}} \pm 4.21$ & $104.06^{c} \pm 4.98$ & $89.11^{d} \pm 3.67$ \\
\hline Oat bran B* & $118.81^{\mathrm{a}} \pm 4.66$ & $121.09^{\mathrm{a}} \pm 2.82$ & $119.44^{\mathrm{a}} \pm 5.09$ & $117.61^{\mathrm{a}} \pm 3.81$ & $106.21^{b} \pm 5.08$ & $87.66^{c} \pm 4.02$ \\
\hline Wheat bran $A^{*}$ & $143.62^{\mathrm{a}} \pm 3.95$ & $141.67^{\mathrm{a}} \pm 7.08$ & $142.28^{\mathrm{a}} \pm 5.82$ & $141.19^{\mathrm{a}} \pm 5.32$ & $135.04^{\mathrm{a}} \pm 5.27$ & $133.06^{\mathrm{a}} \pm 5.55$ \\
\hline Wheat bran $B^{*}$ & $140.67^{\mathrm{a}} \pm 3.90$ & $138.16^{\mathrm{a}} \pm 5.99$ & $139.87^{\mathrm{a}} \pm 5.45$ & $140.22^{\mathrm{a}} \pm 5.23$ & $134.87^{\mathrm{a}} \pm 4.61$ & $132.25^{\mathrm{a}} \pm 5.28$ \\
\hline Cereal products intended for children $\mathrm{A}^{*}$ & $7.87^{\mathrm{a}} \pm 0.35$ & $9.08^{\mathrm{b}} \pm 0.43$ & $10.06^{c} \pm 0.31$ & $11.39^{d} \pm 0.39$ & $9.94^{\mathrm{bc}} \pm 0.35$ & $12.88^{e} \pm 0.44$ \\
\hline Cereal products intended for children $\mathrm{B}^{*}$ & $11.71^{\mathrm{a}} \pm 0.57$ & $12.26^{\mathrm{a}} \pm 0.62$ & $13.09^{\mathrm{a}} \pm 0.51$ & $12.81^{\mathrm{a}} \pm 0.39$ & $12.94^{\mathrm{a}} \pm 0.45$ & $10.09^{b} \pm 0.74$ \\
\hline Cereal products intended for children $C^{*}$ & $12.56^{\mathrm{a}} \pm 0.53$ & $12.14^{\mathrm{a}} \pm 0.52$ & $11.84^{\mathrm{a}} \pm 0.54$ & $12.19^{\mathrm{a}} \pm 0.45$ & $12.83^{\mathrm{a}} \pm 0.59$ & $10.92^{b} \pm 0.71$ \\
\hline Cereal products intended for children $D^{*}$ & $24.63^{a} \pm 0.74$ & $23.93^{\mathrm{a}} \pm 0.76$ & $24.34^{\mathrm{a}} \pm 1.14$ & $24.91^{\mathrm{a}} \pm 1.07$ & $25.44^{\mathrm{a}} \pm 1.12$ & $25.77^{a} \pm 0.91$ \\
\hline
\end{tabular}

${ }^{*} \mathrm{~A}, \mathrm{~B}, \mathrm{C}$ and $\mathrm{D}$ represent different brands

$a, b-$ statistically significant difference between mean values designated by the identical letters in rows, $p<0.05$

compared to the original value (Tab. 5). $3 \%$ supplementation resulted in a reduction ranging from $20.3 \%-23.3 \%$ for cereal samples and $10.1 \%-14.0 \%$ for other samples; $5 \%$ caused a reduction ranging from $22.1 \%-40.5 \%$ in all samples. Favourable changes in HT-2 content in samples supplemented with a $10 \%$ addition of cinnamon were even higher, ranging from $33.3 \%-56 \%$. A $20 \%$ addition of cinnamon caused a reduction ranging from $37 \%-70.4 \%$, while $30 \%$ caused a reduction ranging from $55 \%-87 \%$. Moreover, the supplementation of products intended for children completely inhibited the formation of mycotoxins. When analyzing the changes in individual groups for this additive, the content of HT-2 toxin decreased from $67.1 \%$ $76.1 \%$ in cereal samples, from $57.5 \%-69.2 \%$ in wheat bran, from $83.4 \%-87.0 \%$ in oat bran, and from $55 \%-100 \%$ in products cereal for children. Correlation analysis showed a strong negative correlation in all tested samples.

Taken together, the results obtained in the current thus show that the addition of compounds with a high antioxidant potential, such as blueberries, cranberry and cinnamon, in an amount that results in an increase of the overall antioxidant potential of the food sample, may inhibit the formation of mycotoxins.
Horvath et al. [32] found that the essential oils of mint and cinnamon effectively inhibit the growth of Fusarium mycelium. Dambolen et al. [33] found the inhibitory effect of essential oils from basil on the production of fumonisin $B_{1}$ by F. verticillioides on maize seeds. Dambolen et al. [34] found that thymol, carvacrol and isoeugenol are most effective on the inhibition of fumonisin $\mathrm{B}_{1}$ formation. Hussain et al. [35] studied the antifungal activity of some chemical compounds (benzoic acid, propionic acid and copper sulfate), herbs/spices (clove, clove oil) and plants (garlic onion) at various concentrations which were shown to inhibit growth of toxin-producing Aspergillus flavus and Aspergillus parasiticus.

In a study by Císarová and Tančinová [36] on the antifungal activity of some essential oils, oregano was found to display highest antifungal activity against Aspergillus flavus strains, and to inhibit the formation of aflatoxin $\mathrm{B}_{1}$. Research by Heidtmann-Bemvenuti et al. [37] showed that natural antifungal agents inhibit the production of fungal biomass and their toxins, suggesting that natural compounds can be considered as alternative synthetic antifungal agents for effective inhibition of F. graminearum and production of trichothecenes. Ferulic acid applied at high concentrations

Table 5. $\mathrm{HT}-2$ toxin content $[\mu \mathrm{g} \mathrm{kg}-1]$ in samples supplemented with cinnamon powder after storage at $28^{\circ} \mathrm{C}$ and $19 \%$ humidity for 14 days.

\begin{tabular}{|c|c|c|c|c|c|c|}
\hline Oat grain & $88.69^{\mathrm{a}} \pm 3.61$ & $68.04^{b} \pm 2.75$ & $59.81^{c} \pm 2.52$ & $49.93^{\mathrm{d}} \pm 17.04$ & $33.18^{\mathrm{e}} \pm 1.36$ & $21.17^{f} \pm 0.78$ \\
\hline Wheat grain & $88.05^{\mathrm{a}} \pm 4.05$ & $70.18^{b} \pm 3.21$ & $62.74^{\complement} \pm 2.47$ & $53.63^{d} \pm 1.51$ & $39.71^{\mathrm{e}} \pm 1.05$ & $28.94^{f} \pm 1.17$ \\
\hline Oat bran $A^{*}$ & $98.02^{\mathrm{a}} \pm 4.26$ & $85.51^{\mathrm{b}} \pm 3.04$ & $58.30^{\complement} \pm 2.07$ & $42.78^{\mathrm{d}} \pm 1.34$ & $31.62^{\mathrm{e}} \pm 1.14$ & $16.23^{f} \pm 0.64$ \\
\hline Oat bran $B^{*}$ & $102.83^{\mathrm{a}} \pm 4.64$ & $90.17^{\mathrm{b}} \pm 4.41$ & $75.04^{\complement} \pm 3.51$ & $51.36^{d} \pm 1.67$ & $30.47^{e} \pm 0.65$ & $13.38^{f} \pm 0.62$ \\
\hline Wheat bran $A^{*}$ & $162.26^{\mathrm{a}} \pm 4.68$ & $140.29^{\mathrm{b}} \pm 4.53$ & $121.21^{c} \pm 3.18$ & $98.78^{d} \pm 2.96$ & $92.48^{\mathrm{e}} \pm 2.76$ & $69.04^{f} \pm 2.56$ \\
\hline Wheat bran B* & $158.22^{\mathrm{a}} \pm 5.47$ & $136.09^{\mathrm{b}} \pm 4.43$ & $102.28^{\complement} \pm 3.89$ & $91.49^{d} \pm 3.72$ & $72.71^{\mathrm{e}} \pm 3.62$ & $48.72^{f} \pm 2.04$ \\
\hline Cereal products intended for children $\mathrm{B}^{*}$ & $10.21^{\mathrm{a}} \pm 0.42$ & $9.11^{\mathrm{b}} \pm 0.25$ & $7.74^{c} \pm 0.31$ & $6.45^{d} \pm 0.31$ & $5.76^{d} \pm 0.41$ & nd \\
\hline Cereal products intended for children $C^{*}$ & $12.03^{\mathrm{a}} \pm 0.41$ & $10.81^{\mathrm{b}} \pm 0.38$ & $9.21^{c} \pm 0.39$ & $8.02^{\mathrm{d}} \pm 0.38$ & $6.82^{\mathrm{e}} \pm 0.28$ & $5.41^{f} \pm 0.25$ \\
\hline Cereal products intended for children $\mathrm{D}^{*}$ & $24.11^{\mathrm{a}} \pm 0.93$ & $20.81^{b} \pm 0.78$ & $16.43^{\mathrm{b}} \pm 0.69$ & $12.51^{c} \pm 0.59$ & $9.72^{\complement} \pm 0.41$ & $5.56^{\mathrm{d}} \pm 0.33$ \\
\hline
\end{tabular}

*A, B, C and D represent different brands

$a, b-$ statistically significant difference between mean values designated by the identical letters in rows, $p<0.05$

nd - non detected (<LOQ) 
Piotr Pokrzywa, Ewa Cieślik, Magdalena Surma. Effect of cereal products supplementation with american blueberries, cranberries and cinnamon on the formation...

Table 6. Correlation coefficient between the antioxidant activity and measured HT-2 toxin content

\begin{tabular}{llcl}
\hline $\begin{array}{l}\text { Type of supplementation } \\
\text { Sample type }\end{array}$ & Blueberry lyophilizate & Cranberry lyophilizate, \\
\hline Oat grain & -0.962 & -0.731 & -0.952 \\
\hline Wheat grain & -0.751 & -0.683 & -0.952 \\
\hline Oat bran A* & -0.898 & -0.942 & -0.924 \\
\hline Oat bran B* & -0.940 & $-0,970$ \\
\hline Wheat bran A* & -0.793 & -0.910 \\
\hline Wheat bran B* & -0.956 & -0.870 \\
\hline Cereal products intended for children A* & -0.928 \\
\hline Cereal products intended for children B* & -0.968 \\
\hline Cereal products intended for children $C^{*}$ & -0.924 & -0.930 \\
\hline Cereal products intended for children $D^{*}$ & -0.842 & -0.943 \\
\hline
\end{tabular}

(20-25 $\mathrm{mM})$ inhibited the production of fumonisin by Fusarium verticillioides and Fusarium proliferatum [38].

Available literature provides data confirming not only antifungal properties of these compounds but also antibacterial. Shan et al. [39] showed the antibacterial activity of cinnamon, oregano, clove, pomegranate peel and grape seed extracts against Listeria monocytogenes, Staphylococcus aureus and Salmonella enterica in raw pork. A recent study by Tamkute [40] also showed a high effectiveness of the addition of cranberry water and alcohol extracts against pathogenic Listeria monocytogenes, and some other bacteria (Brochothrix thermospacta, Pseudomonas putida, lactic acid bacteria, etc.) in pork meat and meat products during storage in cold stores for 16 and 40 days.

\section{CONCLUSIONS}

The natural products used in study (blueberry, cranberry, cinnamon) inhibited the formation of mycotoxins from the group of trichothecenes. A direct correlation was also found between mycotoxin formation and antioxidant potential. It should also be noted that the addition of these compounds may affect the flavour and aroma of the final product. Therefore, assessing the consumer acceptance will be required before releasing such a food product.

This work is a part of PhD thesis of Piotr Pokrzywa.

\section{REFERENCES}

1. Postupolski J, Starski A, Ledzion E, Kurpińska-Jaworska J, Szczęsna M. Exposure assessment of infants and young children on selected Fusarium toxins. Annals of the National Institute of Hygiene. 2019; 70, 5-14. https://doi.org/10.32394/rpzh.2019.0050.

2. Sorrenti V, Di Giacomo C, Acquaviva R, Barbagallo I, Bognanno M, Galvano F. Toxicity of Ochratoxin A and its modulation by antioxidants: A review. Toxins. 2013; 5, 1742-1766.

3. Bhupendra S, Kharayat, Yogendra Singh. Mycotoxins in Foods: Mycotoxicoses, Detection, and Management Microbial Contamination and Food Degradation, A volume in Handbook of Food Bioengineering. 2018; 395-421.

4. Foroud NA, Eudes F. Trichothecenes in Cereal Grains. Int J Molecular Sci. 2009; 10, 147-173. doi:10.3390/ijms10010147.

5. Commission Regulation (EC) No 1881/2006 of 19 December 2006 setting maximum levels for certain contaminants in foodstuffs. Official Journal of the European Union, 2006; L 364, 5-24 (consolidated version).

6. European Commission, Commission Recommendation of $27 \mathrm{March}$ 2013 on the presence of T-2 and HT-2 toxin in cereals and cereal products. Official Journal of the European Union. 2013; L 91, 12-15.
7. Mylona K, Magan N. Fusarium langsethiae: Storage environment influences dry matter losses and T2 and HT-2 toxin contamination of oats. J Stored Products Res. 2011; 47, 321-327.

8. Medina A, Magan N. Temperature and water activity effects on production of T-2 and HT-2 by Fusarium langsethiae strains from north European countries. Food Microbiol. 2011; 28, 392-398.

9. Reddy KRN, Farhana NI, Salleh B, Oliveira CAF. Microbiological Control of Mycotoxins: Present Status and Future Concerns. Current Research, Technology and Education Topics in Applied Microbiology and Microbial Biotechnology (A. Méndez-Vilas, Ed.). 2013, Formatex.

10. Prakash B, Singh P, Kedia A, Dubey NK. Assessment of some essential oils as food preservatives based on antifungal, antiaflatoxin, antioxidant activities and in vivo efficacy in food system. Food Res Int. 2012; 49, 201-208.

11. Piotrowska A, Góralczyk M, Żebrowska-Krasusk M. Berries and their preserves as sources of antioxidants. Technological Progress in Food Processing. 2013; 2: 96-102.

12. Baranowska M, Bartoszek A. Antioxidant and antimicrobial properties of bioactive phytochemicals from cranberry. Adv Hygiene Exp Med. 2016; 70, 1460-1468.

13. Przygodzka M, Zielińska D, Ciesarová Z, Kukurová K, Zieliński H. Comparison of methods for evaluation of the antioxidant capacity and phenolic compounds in common Spice. Food Sci Technol. 2013; 58: 321-326. http://dx.doi.org/10.1016/j.lwt.2013.09.019.

14. Król S, Kapka-Skrzypczak L. Pharmacological activity of essential oils and their components in the treatment of gastrointestinal diseases. General Medicine and Health Sciences. 2011; 17, 4, 202-205.

15. Prakash B, Singh P, Mishra PK, Dubey NK. Safety assessment of Zanthoxylum alatum Roxb. essential oil, its antifungal, antiaflatoxin, antioxidant activity and efficacy as antimicrobial in preservation of Piper nigrum L. fruits. Int J Food Microbiol. 2012; 153, 183-191.

16. Viuda-Martos M, Mohamady MA, Fernandez-Lopez J, Abd ElRazik KA, Omer EA, Perez-Alvarez J. A. In vitro antioxidant and antibacterial activities of essentials oils obtained from Egyptian aromatic plants. Food Control. 2011; 22: 1715-1722.

17. Kocić-Tanackov SD, Dimić GR. Antifungal activity of essential oils in the control of food-borne fungi growth and mycotoxin biosynthesis in food. Microbial pathogens and strategies for combating them: science, technology and education (A. Méndez-Vilas, Ed.) 2013, Formatex.

18. ISO 712:2009. Cereals and cereal products. Determination of moisture content.

19. ISO 21527-1:2009 Microbiology of food and animal feeding stuffs. Horizontal method for the enumeration of yeasts and moulds. Part 1: Colony count technique in products with water activity greater than 0,95 .

20. ISO 21527-2:2009 Microbiology of food and animal feeding stuffs. Horizontal method for the enumeration of yeasts and moulds. Part 2: Colony count technique in products with water activity less than or equal to 0,95 .

21. Re R, Pellegrini N, Proteggente A, Pannala A, Yang M, Rice-Evans C. Antioxidant activity applying an improved ABTS radical cation decolorization assay. Free Radical Biology Medicine 1999; 26, 9-10, 1231.

22. Jeleń $H H$, Wąsowicz E. Determination of trichothecenes in wheat grain without sample cleanup using comprehensive two-dimensional gas chromatography-time-of-flight mass spectrometry. Journal of Chromatography A, 2008; 1215: 203-207. 
23. Borowska EJ, Mazur B, Gadzała-Kopciuch R, Buszewski B. Polyphenol, anthocyanin and resveratrol mass fractions and antioxidant properties of cranberry cultivars. J Food Technol Biotechnol. 2009; 47: 56-61.

24. Rodrigues E, Poerner N, Rockenbach II, Gonzaga LG, Mendes CR, Feti R. Phenolic compounds and antioxidant activity of blueberry cultivars grown in Brazil. Ciênc Tecnol Aliment Campinas. 2011; 31: 911-917.

25. Filipiak-Florkiewicz A, A Florkiewicz, Dereń K. Content of bioactive compounds in selected processed cereal products. Bromatology Toxicol Chem. 2016; 2: 194-2002.

26. Pleadin J, Vahcic N, Persi N, Sevelj D, Markov K, Frece J. Fusarium mycotoxins' occurrence in cereals harvested from Croatian Fields. Food Control. 2013; 32: 49-54.

27. Stuper-Szablewska K., Perkowski J. Contamination of wheat grain with microscopic fungi and their metabolites in Poland in 2006-2009. Ann Agric Environ Med. 2014; 21(3): 504-509.

28. Suproniene S, Justesen AJ, Nicolaisen M, Mankeviciene A, Dabkevicius Z, Semaskiene R, Leistrumaite A. Distribution of trichothecene and zearalenone producing Fusarium species In grain of different cereal species and cultivars grown under organic farming conditions in Lithuania. Ann Agric Environ Med. 2010; 17: 79-86.

29. Rodríguez-Carrasco Y, José Ruiz M, Font G, Berrada H. Exposure estimates to Fusarium mycotoxins through cereals intake. Chemosphere. 2013; 93: 2297-2303.

30. Twarużek M, Grajewska-Wanat N, Błajet-Kosicka A, Grajewski J. Occurrence of Fusarium and major mycotoxins in cereal grains harvested in 2011-2012. Progress in plant protection. 2013; 53, 4.

31. Czerwińska E, Kubiak MS. The influence of packaging on microbiological purity and selected physicochemical properties of bran. Probl Hyg Epidemiol. 2013; 94(2): 294-299.

32. Horvath A, Kovacs B, Nagy G. Application of mint and cinnamon against Fusarium disease of winter wheat. Episteme. 2013; 18(3): 297-304.
33. Dambolena JS, Zunino PM, López GA, Rubinstein HR, Zygadlo JA, Mwangi WJ, Thoithi NG, Kibwage OI, Mwalukumbi MJ, Kariuki TS. Essential oils composition of Ocimum basilicum L. and Ocimum gratissimum L. from Kenya and their inhibitory effect on growth and fumonisin production by Fusarium verticillioides. Innovative Food Science and Emerging Technologies. 2010; 11(2): 239-422.

34. Dambolena JS, Zygadlo JA, Rubinstein HR. Antifumonisin activity of natural phenolic compounds. A structure-property-activity relationship study. Int J Food Microbiol. 2011; 145: 140-146.

35. Hussain A, Shafqatullah Ali J, Zia-ur-Rehman. Inhibition of aflatoxin producing fungus growth using chemical, herbal compounds/spices and plants. Pure and Applied Biology. 2012; 1: 8-13.

36. Císarová M, Tančinová D. Antimicrobial Properties of Selected Essential Oils in Vapour Phase against Aspergillus flavus. Animal Sci Biotechnol. 2015; 48: 2.

37. Heidtmann-Bemvenuti R, Tralamazza SB, Ferreira CFJ, Corręa B, Badiale-Furlong E. Effect of natural compounds on Fusarium graminearum complex. J Sci Food Agric. 2016; 96: 3998-4008, doi: 10.1002 /jsfa.7591.

38. Ferrochio L, Cendoya E, Farnochi MC, Massad W, Ramirez ML. Evaluation of ability of ferulic acid to control growth and fumonisin production of Fusarium verticillioides and Fusarium proliferatum on maize based media. International J Food Microbiol. 2013; 167: 215-220.

39. Shan B, Cai Y-Z, Brooks JD, Corke H. Antibacterial and antioxidant effects of five spice and herb extracts as natural preservatives of raw pork. J Sci Food Agric. 2009; 89: 1879-1885.

40. Tamkutė L, Gil BM, Carballido JR, Pukalskienė M, Venskutonis PR. Effect of cranberry pomace extracts isolated by pressurized ethanol and water on the inhibition of food pathogenic/spoilage bacteria and the quality of pork products. Food Res Internat. 2019; 120: 38-51. 